wonderful paper by Peterman ${ }^{2}$; that seminal contribution should have what I term here the "statistical scrotal effect" - it should cool the ardour of most hypothesis testers (testees?).

Stephen M. Smith

Department of Biology,

University of Waterloo,

Waterloo, Ontario, Canada N2L $3 G 1$

1. Nieschlag, E., Nieschlag. S. \& Behre, H. M. Nature 366, 215(1993).

2. Peterman, R. M. Can. J. Fish aquatic Sci. 47, 2-15 (1990).

\section{Stomach NO synthesis}

SIR - In man, nitrate is concentrated in the saliva and rapidly converted to nitrite by facultative anaerobic bacteria on the surface of the tongue $e^{1-3}$. In the stomach, acidification of this nitrite will result in the
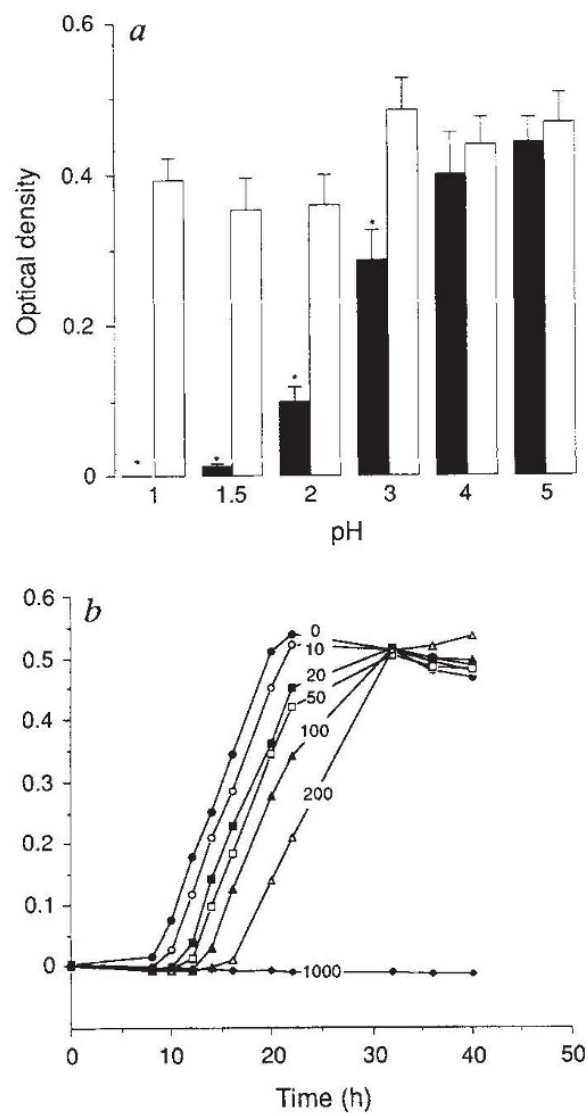

a, Effect of exposure to nitrite and differing hydrogen ion concentrations on the survival of C. albicans. Open bars, growth of C. albicans, measured by optical density, in Sabarouds broth, $9 \mathrm{~h}$ following exposure to acid alone (phosphate/citrate buffer) for $1 \mathrm{~h}$. Closed bars, growth following exposure to acid and $250 \mu \mathrm{M}$ sodium nitrite. Asterisk, significant difference from control $(P<0.05$, MannWhitney $U$ test, mean of 20 experiments). $b$, Growth curves of $E$. coli in nutrient broth (Oxoid CM1) following exposure to phosphate/citrate buffer, $\mathrm{pH} 3$, with increasing concentrations of nitrite $(\mu \mathrm{M})$ for $1 \mathrm{~h}$. Mean of 16 experiments. formation of nitrous acid ( $\mathrm{p} K_{\mathrm{a}} 3.2$, equation 1) and then nitrogen oxides (equations 2,3). We propose that this novel mechanism for NO (nitric oxide) generation in the lumen of the stomach is important as a defence against swallowed pathogenic microorganisms.

$$
\begin{gathered}
\mathrm{NO}_{2}{ }^{-}+\mathrm{H}^{+} \rightleftarrows \mathrm{HNO}_{2} \\
2 \mathrm{HNO}_{2} \rightleftarrows \mathrm{H}_{2} \mathrm{O}+\mathrm{N}_{2} \mathrm{O}_{3} \\
\mathrm{~N}_{2} \mathrm{O}_{3} \rightleftarrows \mathrm{NO}^{\bullet}+\mathrm{NO}_{2}^{\bullet}
\end{gathered}
$$

We tested the saliva of ten people working in our laboratory who had fasted overnight. Salivary nitrite varied from 23 to $220 \mu \mathrm{M}$ (mean 114) rising to $409-1,890$ $\mu \mathrm{M}$ (mean 1,030) 45 min following ingestion of $200 \mathrm{mg}$ potassium nitrate solution. Nitrite solutions generate NO on acidification at a rate dependent on both nitrite and hydrogen-ion concentration; $200 \mu \mathrm{M}$ nitrite, when acidified to $\mathrm{pH} 2$, results in an NO concentration of approximately $600 \mathrm{nM}$, several orders of magnitude greater than that required to cause vasodilation ${ }^{4}$.

The yeast Candida albicans retains viability when incubated with acid alone for an hour at $\mathrm{pH} 3$ but is destroyed when $250 \mu \mathrm{M}$ nitrite is added to the incubation medium ( $a$ in the figure). Escherichia coli, which is closely related to Salmonella sp., Shigella sp. and other pathogenic Enterobacteriaceae, when incubated for $1 \mathrm{~h}$ at $\mathrm{pH} 3$ shows sensitivity to as little as $10 \mu \mathrm{M}$ nitrite ( $b$ in the figure). As more than 1 litre of saliva is usually swallowed each day, it is likely that microbicidal concentrations of nitrite exist in the stomach, especially in people consuming a highnitrate diet (mainly provided by green vegetables in developed countries) ${ }^{5}$.

NO, which is generated when nitrite is acidified, readily diffuses through cell membranes and has a high affinity for iron-sulphur-containing respiratory enzymes and damages bacterial $\mathrm{DNA}^{6}$. When produced enzymatically by activated leukocytes, nitric oxide will kill various gut pathogens ${ }^{7-11}$.

Although there has been concern that the enterosalivary circulation of nitrate

1. Sasaki, T. \& Matano, K. J. Fd Hyg. Soc. Jap. 20, 363-369 (1979)

2. Ishiwata, H., Tanimura, A. \& Ishidate, M. J. Fd Hyg. Soc. Jap. 16. 89-92(1975).

3. Tannenbaum, S. R., Weisman, M. \& Fett, D. FdCosmet. Tox. 14. 549-552 (1976)

4. Palmer, R. M. J., Ferrige, A. G. \& Moncada, S. Nature 327, 524-526 (1987)

5. Knight, T. M., Forman, D., Al-Dabbah, S. A. \& Doll, R. Fd Chem. Tox. 25, 277-285 (1987)

6. Wink. D. A. et al. Science 254, 1001-1003 (1991)

7. Liew, F. Y., Li, Y. \& Millott, S. J. Immun. 145, 4306-4310 1990).

8. Malawista, S. E., Montgomery, R. R. \& van Blaricom, G. J clin. Invest. 90, 631-636 (1992).

9. Green, S. J. et al. Infect. Immuninty. 61.689-698 (1992)

10. Denis, M. J. Leuk. Biol. 48, 380-387 (1991)

11. Cenci. E. et al. Eur. J. Immun. 23, 1034-1038 (1993).

12. Tannenbaum, S. R., Sinskey, A. J. \& Bishop, W. J. natn Cancerinst. 53, 79-84 (1974).

13. Spiegelhalder, B., Eisenbrand, G. \& Preussmann, R. Fd Cosmet. Tox. 14, 545-548(1976). may result in the formation of harmful nitrosamines $^{12,13}$, we suggest that this alternative route of NO synthesis has developed for the specific purpose of prevention of lower gastrointestinal infection.

Although we have considered the effect of acidified nitrite only on $C$. albicans and $E$. coli, this mechanism may also be important in providing protection from other serious gut pathogens which, when swallowed, may cause duodenal ulceration (Helicobacter pylori), amoebic dysentery and chronic intestinal parasitism.

Nigel BenJamin, Fionnuala O'Driscoll, Hamish Dougall, Callum Duncan, Lorna Smith \& Michael Golden Department of Medicine and Therapeutics, Hamish McKenzie

Department of Medical Microbiology, University of Aberdeen

Medical School,

Forresterhill, Aberdeen AB9 2ZD, UK

\section{Viral-induced extinctions unlikely}

SIR - Emiliani in Scientific Correspondence ${ }^{1}$ implies that the existence of phytoplankton-infecting viruses, including viruses that may constrain the blooms of phytoplankton ${ }^{2}$, provides support for viral-induced extinctive evolution. Emiliani had earlier proposed ${ }^{3}$ that the sudden extinctions and appearances of marine protists could be due to pathogen (fungal and virus) infestations. But in my view, viral pathogen-induced extinctions seem unlikely.

Viruses are obligate parasites, and their survival depends on the survival of the host. If a virulent virus reduced the population of its host, the virus population would similarly be reduced until a balance (steady state) was achieved. Indeed, the phytoplankton-infecting viruses ${ }^{2}$ reduced the ability of phytoplankton to grow only when the cultures reached stationary phase. A virulent virus can only eliminate a host population if the virus can also live in another host which it does not kill. In the absence of an alternative host population for these viruses it is improbable that lethal mutant viruses arose repeatedly during evolution and completely eliminated their hosts. The finding of an alternative host organism for these viruses would provide more compelling support for Emiliani's theory of extinctive evolution ${ }^{3}$.

\section{Vlctor E. Buckwold}

Department of Microbiology,

University of Southern California

School of Medicine,

Los Angeles, California 90033, USA

1. Emiliani, C. Nature 366, 217-218 (1993)

2. Shuttle, C. A., Chan, A. M. \& Cottrell, M. T. Nature 347 467-469 (1990)

3. Emiliani, C.J. theor. Biol. 97, 13-33(1982) 